on January 15. This proved to be a comprehensive account of the history of the dyestuffs industry in Great Britain, and traced the development and expansion of the chemist's skill and the dyer's needs since Sir W. H. Perkin's original discovery in 1856. Perhaps the most interesting section of the address was the examination of the causes which produced the rise, and then, in England, the decline of the new manufacture. In the first place, the time was ripe for such a discovery because the successful application of machinery to the textile industries and the increase in available wool (from Australia) offered almost unlimited expansion, and also as England was a wealthy country and the workshop of the world. As for the decline, Perkin himself attributed it to three causes: the Patent laws, the ease of infringement abroad, and foreign import duties. Others have blamed the textile manufacturers and the greater facilities for scientific publication in Germany at that time, but Mr. Cronshaw placed above these, lack of foresight, and the fact that the leaders of the industry retired too soon. Perkin was certainly the leading technologist of his day, and he retired at the age of thirty-six years, Caro at thirty-five in 1869, and Nicholson in 1868. Perhaps the early success was too easy, and proved to be dearly bought.

\section{Queen Maud Ranges of Antarctica}

The American expedition to the Bay of Whales in the Ross Sea is reported by The Times to have undertaken a most successful dog-sledge expedition to the Queen Maud Ranges, which amplifies the work of Dr. L. M. Gould of the previous Byrd expedition of 1929-30. A party of three under Mr. Q. A. Blackburn reached the Thorne glacier, which lies in about lat. $86^{\circ} \mathrm{S}$., long. $153^{\circ} \mathrm{W}$., and then ascending the glacier reached the surface of the polar plateau at an elevation of about seven thousand feet. The ranges appear to continue with decreasing heights to the north of east. This direction may lead to Coats Land in the Weddell Sea or possibly towards Hearst Land. At the top of the glacier, deposits of coal are reported to have been found. This would appear to be the same deposit found on the Beardmore glacier and the carbonaceous layer found in the flank of Mount Nansen. There is thus a confirmation of the suggestion made some years ago by Sir Edgeworth David of a great coalfield associated with the Beacon sandstone of the polar plateau. The brief cabled report also refers to a subplateau at an elevation of $2,500 \mathrm{ft}$. between the Ross Sea ice and the level of the polar plateau. This was called the Leverett glacier in 1929. The sledge party reached three degrees from the Pole before turning back, and altogether covered 1,410 miles in 88 days.

\section{Effect of Rough Seas on Marine Structures}

ON February 2-3, 1934, a storm of exceptional severity was experienced along the northern coast of Africa and led to the destruction of more than $1,300 \mathrm{ft}$. of the recently constructed Mustapha Breakwater at Algiers. The storm and the damage done is described by Dr. B. Cunningham in Engineer. ing of January 11. There are several moles protecting the Port of Algiers, but whereas the older ones are rubble mounds, the Mustapha Breakwater consisted of a vertical wall $11 \mathrm{~m}$. thick with its base resting on a rubble foundation $50 \mathrm{ft}$. below mean sea-level. It was recognised as one of the finest examples of its kind. The wall successfully withstood a severe storm on December 31, 1933, when it was subject to waves $6-6 \frac{1}{2} \mathrm{~m}$. in height and $100-120 \mathrm{~m}$. in length, but was completely destroyed by the storm of February 2-3, 1934. Observations made during this storm showed that the wall was being subject to the action of waves $9 \mathrm{~m}$. in height, $200 \mathrm{~m}$. long and with a period of $13 \frac{3}{4}$ seconds, and photographs taken show unbroken masses of water 2-6 m. thick passing over it. There were three stages in its destruction : (1) erosion of the bed of the sea in front of the rubble foundation, (2) the sudden removal of the rubble foundation by one or more great waves, and (3) the excavation by the sea of a trench into which the wall collapsed. It has been generally thought, says Dr. Cunningham, that a level of about $40 \mathrm{ft}$. below the sea-surface marked the limit of appreciable dislocation of rubble foundation mounds by wave action, but this view now needs reconsideration, and it is clear that the effective suction of a back draught following wave stroke may extend to depths far below the accepted standard. Fortunately, the failure of the mole did not lead to damage to shipping in the harbour. It has now been decided to replace the wall at once with a breakwater of the classic mound type.

\section{Removal of Smoke and Acid Constituents from Flue Gases}

Practical remedies for preventing or reducing the emission of objectionable constituents in flue gases have in the past been mainly confined to the elimination of grit and dust emission. In large urban areas it is now realised that the acid emission is attended with more serious consequences. In 1927, Parliamentary sanction was only given to the erection of Battersea Power Station on the condition that the best practicable means should be taken to remove the oxides of sulphur from the flue gases. In a paper on a new method of removing smoke and acid constituents from flue gases read on January 7 to a joint meeting of the Institute of Fuel and the Institution of Electrical Engineers by Dr. J. L. Pearson, G. Nonhebel and P. H. N. Ulander, it was stated that the daily combustion of 1,000 tons of average coal in addition to grit, dust and tarry matter, leads to the formation of 45 tons of sulphuric acid, 3-7 tons of nitric acid and half a ton of hydrochloric acid. It is clear that when wet washing is applied, a non-effluent system must be used. The new system is a recirculating, non-effluent water system, from which the grit, dust and ashes are separated and removed as solids. A pilot plant was erected at Billingham, and was subjected to a twentymonths' running test. The water used was a hard surface water drawn from a local stream. Lime was used as the alkali for most of the test, and chalk was used for the remainder. Very satisfactory results were obtained. 97-99 per cent of the sulphur oxides 
were removed, $90-93$ per cent of the hydrochloric acid and 97-98 per cent of the grit and dust from the pulverised fuel boiler. The exit gas from the plant is so free from sulphur dioxide that it is practically odourless, although the sense of smell can detect a very minute trace of this gas.

\section{River Flow Records}

The paper on "Flow of the River Dee" (Aberdeenshire), by Capt. W. N. MeClean, read before the British Association meeting at Aberdeen last September, has been issued in pamphlet form, reprinted from Engineering, with a memorandum which indicates the progress made in the survey of the river subsequent to the original date of the paper, and an addendum illustrating the manner in which the records are to be set out in tabular form for publication. The Dee has a catchment area of 790 sq. miles to Aberdeen, and for the purposes of the survey it was divided into four subsidiary areas, with flow-gauging stations at Balmoral, Dennet, Cairnton and Cults. The author states that he has found that the summer flow in certain Scottish rivers of about 100 to 700 sq. miles catchment, may be taken, roughly, as from $1 / 5$ to $1 \mathrm{cu}$. $\mathrm{ft}$. per sec. per sq. mile, according to area. Flood flows are much more complicated. The author further notes the difficulty of measuring low flows with current meters, as they are at present not very reliable for velocities of less than $1 \mathrm{ft}$. per sec. He suggests the difficulty may be overcome in the future by a temporary contraction of the channel, so as to increase the velocity. Two types of apparatus are in use on the Dee: namely, one in which the meter is suspended from a wire and another in which a rod is the means of support. It is known that, in turbulent flows, the wire-suspended meter tends to set to the current and to give excessively high values. The combined use of the two methods enables a serviceable comparison to be made of their respective accuracies. "The records obtained should prove of great public utility and the co-operation of two authorities directly interested, the City of Aberdeen and the Fishery Board of the Dee, has been secured in establishing the gauging stations. Capt. MeClean points out that if there were a recognised association for these river records, the water interests would become subscribing members of the association, receiving the completed records in return for the standard tables of water levels prepared by them. selves.

\section{Thunderstorms in Great Britain}

THE third annual report of the survey of thunder. storms in the British Isles, entitled "Summer Thunderstorms", has been received (Huddersfield : Thunderstorm Census Organisation. 2s. 6d.). Much of it has been written by Mr. S. Morris Bower, the honorary director of the Survey, but articles have been contributed by Sir C. V. Boys on "Progressive Lightning" and by S. T. E. Dark on "Trees Struck by Lightning". The Survey is an amateur enterprise somewhat similar to what the British Rainfall
Organization was in its early stages. Its development is doubtless made more difficult because the economic importance of the distribution of thunderstorms is, at present, less than that of rainfall. There is the further difficulty that the study of thunderstorms cannot be effectively prosecuted apart from the general study of synoptic meteorology, except in limited directions. In the purely statistical problem of obtaining the best possible cartographical representation of the occurrence of thunder, the Survey had the advantage in 1933 of a number of voluntary observers-1,291-nearly four times greater than the number of full climatological stations co-operating with the Meteorological Office, an advantage greater than the numbers alone suggest in that the observers at official stations do not concentrate on one phenomenon. This report deals with some of the statistical results obtained in 1933, and also includes maps showing the number of days on which storms occurred in different parts of the British Isles in each of the months April-September 1932. The frequencies shown give the number of civil days during which one or more thunderstorms pass overhead, and are therefore not comparable with figures based on the international definition of a day of thunderstorm at any place as one on which thunder is heard at that place. The article on "Trees Struck by Lightning" is accompanied by some interesting photographs showing spiral scoring of tree trunks; it can be seen that the lightning may descend the tree either in a left or a right hand spiral. Sir C. V. Boys's article deals with photographic studies of the duration and length of individual flashes, their direction and velocity, and suggests means for initiating a flash by firing a rocket into the thunder cloud, to assist in studies of this kind.

\section{The Imperial Forestry Institute, Oxford}

In the tenth annual report of the Imperial Forestry Institute for the year 1933-34 (Oxford : The Holywell Press Ltd., 1934) it is stated that the number of students was still considerably below normal, owing to the stoppage of the recruitment for the forest services of the Colonial Office, though it compared favourably with the number of the previous year. Apart from regular students, a number of forest officers, at home on leave, and others attended the Institute for short periods to work in the libraries and the laboratories. The Institute is still shorthanded so far as the staff is concerned. During the year, a decree was passed by the University allocating a site within the Parks area for the erection of a new building for the Department of Forestry, including the Imperial Forestry Institute. Some progress has been made in regard to preliminary plans and estimates for the building; but it has not yet been possible to commence building operations owing to lack of sufficient financial provision; this matter, it is said, is receiving further attention. The income of the Institute is made up of grants from the Crown Agents, Dominions and others, Forestry Commission, and the Department of Scientific and Industrial Research. An interesting part of the report is given 